the area south-east and east of Barr the rocks on the two sides of the Southern Uplands Fault are the same, yet the vinquish map shows the same contrast between vinquish and healthy districts as in those parts where the Old Red Sandstone occurs on one side of the fault and the Lower Palæozoic on the other. We have come to the conclusion, therefore, that the nature of the drift is largely responsible for the incidence of the disease.

In general, the Southern Uplands Fault separates a mountainous belt from the comparatively low ground of the Midland Valley. The difference in topography, a conspicuous feature in the landscape of the Knockdon area, may in itself be a factor bearing on the present problem. It has at least been responsible for the restriction of the morainic drift to the country south of the fault and of the boulder clay to the more fertile ground to the north. The boundary between the two types of drift does not actually coincide with the outcrop of the fault, but the disease boundary line may not really coincide any better. One reason behind the distribu. tion of the disease may, therefore, be the physical state of the subsoil, for the two types just mentioned, morainic drift and boulder clay, have been derived from the same parent rocks to the south.

The occurrence of vinquish on the felsitic outcrops indicates that in certain cases in our area there is a direct relationship between rock, subsoil, soil, herbage and morbid condition of the grazing animals.

\footnotetext{
'Marston, H. R., et al. Comm. Austral. Coun. Sci. and Indust. Res. Bull. 113 (1938).

${ }^{2}$ Underwood, E. J., and Filmer, J. F., Austral. Vet. J., 11, 84 (1935). - Askew , H. O, and Dixon, J. K. Dept. Sci, and Indust. Res. N.Z. Cawthorn Inst. Pasture and Soils Res. Publ. No. 35 (1936).

Ann. Rep. Dept. Agric. Kenya Colony 1936, 2, 87 (1937).

s Patterson, J. B. E., Nature, 140, 363 (1937).

- Corner, H. H., and Smith, A. M., Biochem. J., 32, 1800 (1938).

:Becker, R. B., Neal, W. M., and Sheahy, A. L., Proc. Amer. Soc. An. Prod., 48 (1931)

8 Greig, J. R., Dryerre, H., et al., Vet. J., 89, 99 (1933).

- Archibald, J. G., et al., J. Dairy Sci., 21, 59 (1938).

${ }^{10}$ Marston, H. R., J. Coun. Sci, and Indust. Res. (Aust.), 8, 111 (1935).

11 Elder, S., and McCall, R. J. S., J. Agric. Sci., 26, 1 (1936).
}

\title{
WHAT IS A PHYSICIST?
}

$\mathrm{D}^{\mathrm{u}}$ URING the War of 1914-18 a physics student applied for postponement of military service to enable him to sit for his university examination. One member of the tribunal asked if the student would not be better occupied at a base hospital. Nobody saw the connexion until two words of explanation were given--."mixing physic". At the same time rumour had it that certain physicists working on radio-telegraphy were described officially as chemists because the Services had not officially heard of the term physicist. More recently the literature of popular science has helped to spread the idea that a physicist is essentially a splitter of atoms. In a leading article in the November number of the Journal of Applied Physics, published by the American Institute of Physics, fears are expressed that the services of physicists are liable to be neglected because service and business officers are still under the impression that physicists "being only interested in atoms" cannot be expected to be of much assis. tance.

The definition given by the Institute of Physics in Great Britain to the Ministry of Labour and National Services' Central Register was as follows: "A Physicist is one who has knowledge of, and experience in, one or more branches of physics. Physics includes the study of (I) the properties and nature of matter, (2) heat, (3) light (optics), (4) sound (acousties), (5) electricity, (6) magnetism, (7) radio-activity ; and their applications. Note. The technical application of certain branches of physics have become branches of engineering." With the Schedule of Reserved Occupations, the Ministry of Labour and National Service uses the definition: "Physicist-is engaged in the study of matter and its general properties as affected by the application of various forms of energy ; may be specialized, e.g., in mechanics, heat, light, sound, electricity, radio-activity; the usual qualification is membership of the Institute of Physics and/or a University degree."

When the order for compulsory registration was made in July 1940 any person was considered a physicist who possessed an honours degree in physics of any university of the British Empire, and who was normally engaged as a physicist at any university or in any industry or as a teacher of physics. The number registered under that order was 1,175 . Previously, 1,596 persons had registered voluntarily as physicists. Not only in Great Britain is there a scarcity of physicists. In the United States, accord. ing to an announcement in the February number of the Review of Scientific Instruments, the U.S. Civil Service Commission had to extend the closing date for receipt of applications for entry to the civil service examinations for physicists. The salaries attached to the posts were : physicist (any specialized branch), 3,800 dollars a year; principal, 5,600 dollars; senior, 4,600 dollars; associate, 3,200 dollars; and assistant, 2,600 dollars a year.

The difficulties of creating physicists when they are wanted for work in applied physics is perhaps difficult to realize for those who claim to be able to make a soldier from a civilian by giving him ten weeks' training. In its twenty years of life the Institute of Physics in Great Britan has worked hard in urging the importance of physics in industry. This work of national importance has had to be carried out at the cost of members of the Institute. That such work places a severe strain on the resources of the Institute is clear from the difficulties of the American Institute of Physics. Details of the help given by the Chemical Foundation to get the Institute safely launched were given in the thirteenth number of the Rheology Leaflet. When the help ceased, a deficit of 21,845 dollars had been accumulated by December 1937. In 1939 this had been reduced to 12,840 dollars. Now the Rockefeller Foundation has generously helped. In the same number of the Review of Scientific Instruments it is reported that "a drastic decline in foreign dues and subscription income caused by the War in Europe has now threatened to cancel the gains which have been made. In response to the Institute's appeal 
on this account, the Foundation has generously granted the sum of 20,000 dollars to assist the Institute to adjust the publication program to the new circumstances." In the preparation for, and prosecution of, wars the nations seem to have no difficulty in finding huge sums of money. Yet the bulk of research is still carried on by the aid of charity. The dearth of physicists and the financial difficulties of publication are not rherefore surprising. On consideration, it is an odd state of affairs that the publication of scientific work benefiting, or at least used by, the whole world should still be paid for largely by the research workers themselves through their subscriptions to scientific societies.

\section{BANANA FERTILIZER INVESTI- GATIONS IN JAMAICA}

TNVESTIGATIONS of the effect of fertilizers on 1 bananas are few in number, particularly in the great producing areas in the Caribbean region. In Jamaica, where many estates have been long under cultivation, and where Panama disease and soil erosion are tending to force cultivation on to new areas of lower fertility, a full knowledge of fertilizer requirements is rapidly becoming of paramount importance. The results of recent investigations by Croucher and Mitchell (Bull. 19, Dept. Sci. and Agr., Jamaica, 1940) are of both theoretical and practical interest, touching as they do on several aspects of the growth requirements of the Gros Michel banana.

The experiments under discussion were begun in 1932, but a succession of hurricanes and droughts prevented the reaping of several of the earlier crops, affording, incidentally, some impression of the difficulties with which the tropical investigator has to contend. The experiments undertaken were of a qualitative type, designed to give information on the general reaction of the banana to applications of the main plant nutrients. In the four different areas selected for experimental plots, different results were obtained : in one a growth response was obtained from nitrogen applications alone; in a second, response was obtained only when potash was applied, but phosphate improved production in the presence of potash; on the other hand, excess phosphate in the absence of potash adversely affected the quality of the fruit produced; in a third area, response was obtained only when phosphate was applied, but, in the presence of this nutrient, further response resulted from applications of potash and nitrogen; in a fourth area, absence of potash precluded the possibility of obtaining commercial fruit.

This brief statement of some of the results so far obtained indicates the wide and useful field that awaits further exploration. The assessment of yield of bananas is not a simple matter, in that it involves a consideration of $(a)$ the number of 'hands' per bunch, (b) the quality of the individual fruits, (c) the rate of production, and $(d)$ the population of plants per acre. In some areas nitrogen applications produced an increase in the length of individual fruits-a desirable commercial feature; in others, applications of nitrogen and phosphate also increased the length of fruits, whereas adverse results were obtained elsewhere; potash applications tended to offset undesirable effects resulting from phosphate fertilizers.

\section{FORTHCOMING EVENTS}

[Meeting marked with an asterisk is open to the public.]

\author{
Monday, May Ig
}

Royal Geographical Society (at Kensington Gore, London, S.W.7), at 5 p.m.-Dr. Hugh Scott, F.R.S. : "Highlands of Central Ethiopia".

Tuesday, May 20

Royal Institution of Great Britain (at 21 Albemarle Street, London, W.I), at 5.15 p.m.-Sir Joseph Barcroft, F.R.S. : "The Development of Function in the Mammalian Organism".*

\section{Saturday, May 24}

LINNEAN SocIETY oF London (at Burlington House, Piccadilly, London, W.I), at 3 p.m.-Anniversary Meeting.

\section{APPOINTMENTS VACANT}

APpLICATIONs are invited for the following appointments on or before the dates mentioned:

Manntenance Enginek by the British Guiana Government Transport and Harbours Department-The Crown Agents for the Colonies, 4 Millbank, London, S.W.1 (quoting M/9393)

Assistant Enginegr for the Government Federated Malay States Railways - The Crown Agents for the Colonies, 4 Millbank, London, S.W.1 (quoting M/9618).

\section{REPORTS AND OTHER PUBLICATIONS

\author{
(not included in the montwo Books Supplement)
}

Great Britain and Ireland

Liverpool Observatory and Tidal Institute. Annual Report, 1940. Pp. 12. (Birkenhead: Liverpool Observatory.)

How to Make Good Silage : an Illustrated Guide for Dairy Farmers.

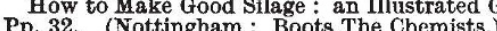

Tin Research Institute. Publication No. 103: Report for 1940 summarising Recent Researches and Developments in the Uses of Tin in Industry. Pp. 24. Publication No. 104: Protective Films on Tinplate by Chemical Treatment. By Dr. R. Kerr. Pp. $14+4$ plates.
(Greenford : Tin Research Institute.)
[15

South-West Essex Technical College and School of Art. Annual Report, Session 1939-40. Pp. $52+12$ plates. (London: South-West Essex Technical College and School of Art, Walthamstow.) [15 Proceedings of the Royal Society of Edinburgh. Section B (Biology), Vol. 61, Part 1, No. 3: The Structure of Tulach Hill, Blair Atholl, Perthshire. By Dr. William J. McCallien. Pp. 43-54. (Edinburgh and London: Oliver and Boyd.) 18. $6 d$.

\section{Other Countries}

Southern Rhodesia Geological Survey. Short Report No. 34 : Geology and Mines of the Mashaba District. By R. Tyndale-Biscoe. Pp. 8. (Salisbury: Geological Survey.)

Gold Coast Colony. Report on the Forestry Department for the Year 1939-40. Pp. 8. (Accra : Government Printing Department : Year 1939-40. Pp. 8. (Accra : Government Printing Department :
London : Crown Agents for the Colonies.)
[284

Commonwealth of Australia: Council for Scientiflc and Industrial Research. Bulletin No. 136: Experimental Studies of Ephemeral Fever in Australian Cattle. By I. M. Mackerras and M. J. Mackerras ; with a Section in collaboration with Dr. F. M. Burnet. Pp. $116+2$ plates. Bulletin No. 137: A Soil Survey of the Red Cliffs Irrigation District, Victoria. By G. D. Hubble and R. L. Crocker. Pp. 63. (Melbourne : Government Printer.)

New Zealand Air Department. Meteorological Observations for 19. Prepared in the Meteorological Office, Wellington (Wellington: Government Printer.) Report of the Aeronautical Research Institute, Tôkyô Imperial University. No. 200: Investigation on the Mechanism of the Cementation of Metals. By the late Masaji Goto, Hirosi Asada and Tuneyosi Okamoto. Pp. 429-476. 90 sen. No. 201: Studies on the Subsonic Flow of a Compressible Fluid past an Elliptic Cylinder. By Susumu Tomotika and Kö Tamada. Pp. 477-552. 1.05 yen. No. 202: Acoustical Studies of the Flutter of an Airscrew (Experiments with Actual Airscrew) (Investigations of Airscrew Flutter, Part 2). By Jaichi Obata, Major Yozô Matumura, Ryô Kanayama and Yahei Yosida. Pp. 553-590. 70 sen. No. 203: On the Mechanism of a New Transformation, and some Associated New-Reactions in the Iron-Nickel Aluminium System. By Syûiti Kiuti. Pp. 591-720. 2.60 yen. (Tôkyố: Kôgyo Tosho Kabushiki Kaisha.) 